\title{
PENGARUH BOOKLET STIMULASI INTERVENSI PERTUMBUHAN DAN PERKEMBANGAN PADA BAYI PREMATUR TERHADAP PENINGKATAN PERTUMBUHAN DAN PERKEMBANGAN BAYI
}

\author{
Rosalinna $^{1}$, Asti Andriyani ${ }^{2}$ \\ Poltekkes Kemenkes Surakarta Jurusan Kebidanan
}

\begin{abstract}
Background: Premature infants have a risk of death in the first year of life mainly due to prematurity. Developmental stimulation interventions in premature infants can have a positive impact on weight gain and infant development. The purpose of this study was to determine the effect of the application of growth and development intervention booklets on mothers who had a premature baby to increase the growth and development of infants aged 0-6 months in Karanganyar Regency. Method: The method used in this study is the method in this study. This research uses a quantitative method with a Quasy experiment in the form of a pre-post test design. The sample in this study was Mother and Baby in Karanganyar District who had met the inclusion and exclusion criteria. Results: The results of this study showed that there were differences in body weight and height growth before and after the study in the control group $(\rho<0.05)$. There were no differences in development before and after the study in the control group $(\rho>0.05)$. There were differences in body weight and height growth before and after the study in the intervention group $(\rho<0.05)$. There are differences in development before and after the study in the control group $(\rho<0.05)$. There is no effect of the application of growth intervention booklet stimulation, but there is a developmental influence on premature infants aged 0-6 months in Karanganyar Regency. Conclusion: SDIDTK booklet can significantly improve the development of premature babies. It is expected that parents can provide stimulation to premature babies well to increase growth and development
\end{abstract}

Keywords: Booklet, Stimulation Of, Growth, Premature Growth

\section{PENDAHULUAN}

Kelahiran prematur telah menjadi perhatian bagi para profesional tenaga kesehatan, dan manajer kesehatan, karena dampak dari deteksi dini dapat memfasilitasi intervensi terapeutik dan meminimalkan masa depan bayi. Dengan demikian, program dibuat untuk mengikuti bayi prematur; Pada kebanyakan kasus, program ini mengikuti bayi 0 bulan sampai anak-anak usia 2 tahun, dan ditujukan terutama untuk mendeteksi kecacatan parah seperti cerebral palsy. Dampak prematuritas seperti mengalami keterbatasan sosial seumur hidup, karena mereka memiliki gangguan ringan, perilaku, kinerja sekolah, dan gangguan bahasa, antara lain, dan seringkali tidak didiagnosis secara spesifik (Rafaela Dkk, 2014)

Secara global, 15 juta bayi lahir prematur setiap tahunnya. Ini setara dengan 1 dari 10 kelahiran. Tingkat kelahiran prematur telah meningkat selama 20 tahun terakhir. Diperkirakan, ini karena meningkatnya usia ibu, 
peningkatan tingkat komplikasi terkait kehamilan. Prevalensi global BBLR adalah $15,5 \%$ yang berjumlah sekitar 20 juta bayi BBLR yang lahir setiap tahun, 96,5\% di antaranya di negara berkembang (Fayed NM, 2016).

Menurut Survey Demografi Kesehatan Indonesia (SDKI) (2012) Data di Indonesia, Angka Kematian Bayi (AKB) terdapat 35 per 1000 kelahiran hidup. Penyebab kematian bayi diantaranya $35,5 \%$ kelahiran prematur, 21,6\% kelahiran BBLR, $17 \%$ kelainan kongenital, $13 \%$ Sepsis, 5,4 lainnya, $5,3 \%$ infeksi pernapasan akut, 1,2\% karena injuri.

Semakin pendek masa kehamilan, semakin besar risikonya kematian dan morbiditas untuk bayi. Bayi prematur memiliki risiko kematian di tahun pertama kehidupan terutama karena prematuritas. Pentingnya pertumbuhan bayi prematur adalah menerima perhatian, stimulasi untuk perkembangan jangka panjang. Sayangnya, pertumbuhan sering merupakan masalah sekunder saat perawatan pasca lahir yang diutamakan adalah pada stabilisasi dan pengelolaan penyakit akut. Tenaga kesehatan harus memberikan stimulasi ritmik yang lembut bentuk sentuhan lembut, pijatan, memeluk, membelai dan melenturkan Stimulus pendengaran yang menenangkan dapat diberikan pada bayi prematur dalam bentuk suara keluarga atau musik (Fayed NM, 2016).

Perkembangan normal pada anak perlu dipantau secara rutin karena dapat dijadikan dasar untuk mengetahui gangguan tumbuh kembang (Soetjiningsih,2015). Penelitian yang dilakukan oleh Mirko, et. al (2017) menunjukkan bahwa gangguan perkembangan motorik saat anak - anak dapat mempengaruhi kecerdasan akademik saat masa sekolah. Penelitian lain yang dilakukan oleh Murray, et.al (2006) menggunakan metode cohort menunjukkan bahwa terdapat pengaruh yang signifikan antara pencapaian kemampuan motorik kasar terhadap kemampuan kognitif di usia 33-35 tahun. Secara singkat, menurut penelitian Barnett et.al (2008) kemampuan motorik yang baik saat balita dapat menurunkan gangguan aktivitas fisik saat masa balita dan kemampuan motorik dalam masa anak - anak berhubungan dengan aktivitas fisik yang baik di masa remaja.

Suatu penelitian di Indonesia yang dilakukan di kabupaten Bandung, Jawa Barat menunjukkan bahwa 20-30\% anak balita mengalami gangguan perkembangan, sebagian besar mengalami keterlambatan pada aspek motorik kasar dan bahasa/bicara ( Kemenkes, 2014 )

Pemerintah memberikan solusi untuk mendeteksi penyimpangan pertumbuhan dan perkembangan anak melalui program Stimulasi Deteksi dan Intervensi Tumbuh Kembang (SDIDTK) yang telah ada sejak tahun 1988. Pemantauan SDIDTK diantaranya dengan melakukan pemantauan motorik kasar dan motorik halus pada bayi dan balita dengan menggunakan Kueisioner Pra Skrining Perkembangan (KPSP). Sehingga penyimpangan pertumbuhan dan perkembangan dapat terdeteksi dini (Kemenkes,2016).

Deteksi dini melalui kegiatan SDIDTK sangat diperlukan untuk menemukan secara dini penyimpangan pertumbuhan, penyimpangan perkembangan dan penyimpangan mental emosional pada anak sehingga dapat dilakukan intervensi dan stimulasi sedini mungkin untuk mencegah terjadinya 
penyimpangan

pertumbuhan,

perkembangan dan mental emosional yang menetap. Kegiatan SDIDTK tidak hanya dilakukan pada anak yang dicurigai mempunyai masalah saja tetapi harus dilakukan pada semua balita dan anak pra sekolah secara rutin setahun 2 kali (Kemenkes, 2016).

Penelitian yang dilakukan oleh Dewi, Feti menunjukkan bahwa SDIDTK terbukti efektif terhadap peningkatan angka penemuan dini gangguan pertumbuhan dan perkembangan anak usia balita dengan $p$ value 0,004 . Hal yang sama pada penelitian yang dilakukan Fayed tahun 2016 menjelaskan bahwa intervensi stimulasi tumbuh kembang pada bayi prematur dapat memberikan dampak positif terhadap penambahan berat badan dan perkembangan bayi

Studi pendahuluan yang dilakukan di Kabupaten Karanganyar didapatkan 157 kematian bayi dari 639 kelahiran pada tahun 2017. Berdasarkan data tersebut terdapat $66(40,2 \%)$ bayi yang meninggal merupakan bayi dengan usia kehamilan kurang dari 37 minggu (Prematur). Penelitian ini bertujuan untuk mengetahui pengaruh penerapan booklet stimulasi intervensi pertumbuhan dan perkembangan pada ibu yang memiliki bayi riwayat prematur terhadap peningkatan pertumbuhan dan perkembangan bayi usia $0-6$ bulan di Kabupaten Karanganyar”.

\section{METODE PENELITIAN}

Metode dalam penelitian ini adalah Penelitian ini menggunakan metode kuantitatif dengan jenis penelitian Perlakuan Semu (Quasy experiment) yang berbentuk pre-post test design. Pada tahap pertama dilakukan pengukuran awal (pre test) pada kedua kelompok. Kemudian setelah itu masing-masing kelompok diberi perlakuan, kemudian pada akhir penelitian dilakukan pengukuran akhir (post test) pada pada minggu keenam Materi inti dari booklet pendidikan kesehatan ini tidak jauh berbeda dengan konseling yang biasa dilakukan oleh bidan tetapi dalam penelitian ini ditambahkan materi untuk meningkatkan pertumbuhan dan perkembangan bayi khususnya bayi prematur. Strategi pendidikan kesehatan dalam kelompok perlakuan menggunakan booklet stimulasi pertumbuhan dan perkembangan dengan bayi yang memiliki riwayat prematur.. Sehingga diharapkan ibu dapat meningkatkan pertumbuhan dan perkembangan bayi. Lokasi penelitian terdiri Penelitian dilakukan di Kabupaten Karanganyar Jawa Tengah. Penelitian ini dapat dilaksanakan pada 6 dari 21 Puskesmas yang ada di Kabupaten Karanganyar. Ketetapan tempat ini berdasarkan per-timbangan peneliti yang puskesmasnya memiliki angka kelahiran prematur terbanyak. Pertimbangan untuk puskesmas kontrol dan perlakuan berdasarkan letak Puskesmas agar tidak saling berdekatan. Waktu pelaksanaan penelitian adalah, yaitu 15 Juli -20 September 2018. sampel dalam penelitian ini adalah 16. Untuk masik masing kelompok ( kontrol dan perlakuan). Pada akhir penelitian jumlah subjek pada kelompok perlakuan terjadi lost to follow up karena meninggal 1 orang. Analisis data dilakukan dengan menggunakan uji beda berpasangan dan tidak berpasangan.

\section{HASIL PENELITIAN}

Penelitian penerapan Penerapan Booklet Stimulasi Intervensi Pertumbuhan Dan Perkembangan Pada Ibu Yang Memiliki Bayi Riwayat Prematur 
Terhadap Peningkatan Pertumbuhan Dan Perkembangan Bayi Usia 0-6 Bulan ini dilaksanakan pada 15 Juli - 20 September di 4 Puskesmas Kabupaten Karanganyar. Proses pembuatan booklet ini telah dikembangkan sejak April 2018 dengan membuat rencana pendidikan kesehatan melalui booklet pada orang tua dengan riwayat bayi prematur.

Proses penelitian dilakukan dengan mengidentifikasi Puskesmas yang memiliki prevalensi BBLR lebih. Sebanyak 2 Puskesmas digunakan untuk Puskesmas Kontrol dan 2 Puskesmas Perlakuan. Pemilihan Puskesmas ini disesuaikan lokasi puskesmas agar puskesmas kontrol tidak berdekatan dengan puskesmas perlakuan.

Data yang dikumpulkan melalui kuesioner yang dilakukan sebanyak empat kali. Data yang terkumpul dilakukan analisis deskriptif dan kuantitatif untuk menganalisis pengaruh Penerapan Booklet Stimulasi Intervensi Pertumbuhan Dan Perkembangan Pada Ibu Yang Memiliki Bayi Riwayat Prematur Terhadap Peningkatan Pertumbuhan Dan Perkembangan Bayi Usia 0-6 Bulan..

Berdasarkan tabel 1 dapat dijelaskan karakteristik pada kedua kelompok. Berdasarkan umur ayah pada kelompok kontrol 36,5 $(6,27)$ tahun sedangkan pada kelompok intervensi lebih muda 32,5 $(7,70)$ tahun. Pada umur ibu kelompok kontrol 34,2 $(5,67)$ tahun sedangkan pada kelompok intervensi lebih muda 29,8 $(8,17)$ tahun. Berdasarkan pendidikan sebagian besar merupakan pendidikan dasar baik pada kelompok kontrol $(62,5 \%)$ maupun kelompok intervensi $(60 \%)$. Berdasarkan pendapatan pada kelompok kontrol 3.318.750 (159.247) rupiah sedangkan pada kelompok intervensi lebih rendah yaitu 2.420 .000
(1.154.618) rupiah. Berdasarkan riwayat perawatan sebagian besar tidak memiliki riwayat perawatan baik pada kelompok kontrol (87,5\%) maupun kelompok intervensi (80\%). Hasil uji statistik didapatkan bahwa tidak ada perbedaan karakteristik yang bermakna $(\rho>0,05)$ pada kedua kelompok. Hal ini berarti pada kedua kelompok homogen dan dapat untuk dibandingkan.

Tabel 1. Karakteristik Subjek Penelitian

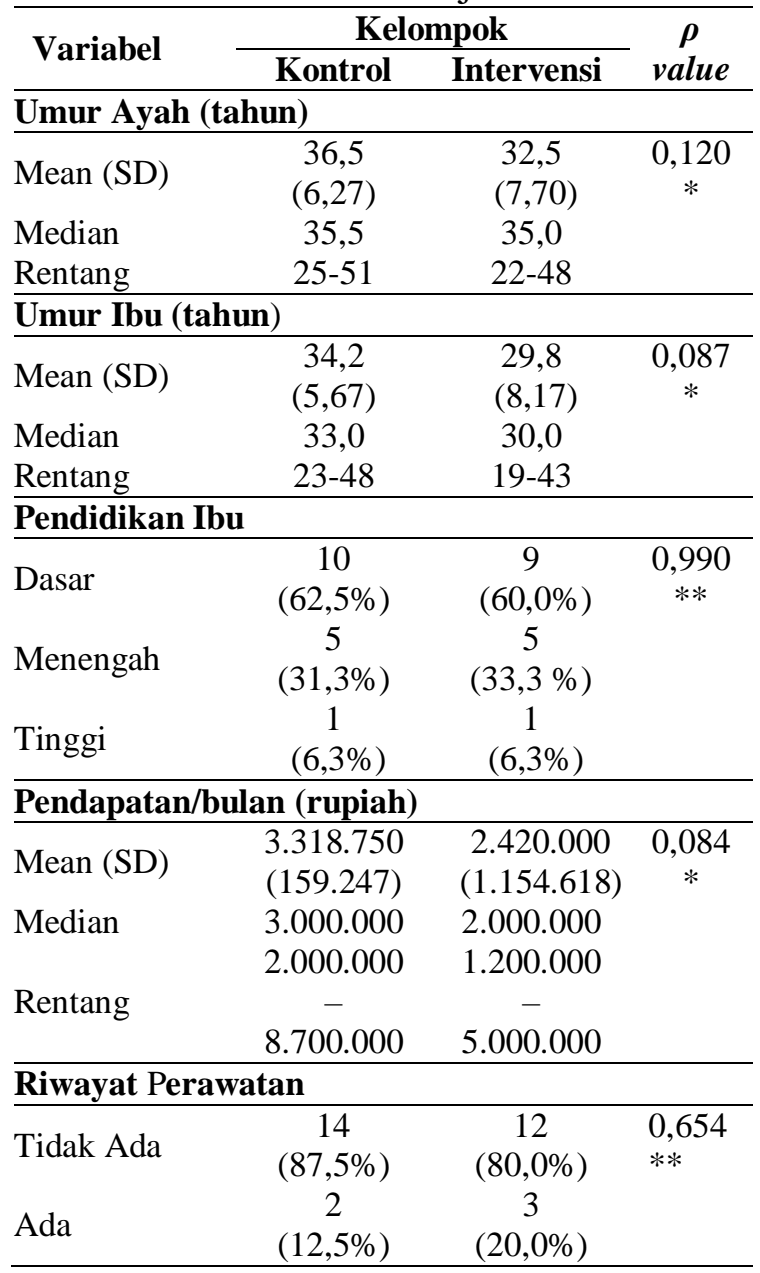

Keterangan uji: *) T Independent, **) Chi square

Pada tabel 1 didapatkan hasil data pertumbuhan dan perkembangan pada kelompok kontrol. Pada data pertumbuhan menurut berat badan didapatkan sebelum penelitian dengan rata-rata 5.625,0 
$(1.216,2)$ gram dan terjadi peningkatan setelah penelitian menjadi dengan ratarata 6.118 (1.218) gram. Pada data panjang badan didapatkan sebelum penelitian dengan rata-rata $57,1(4,56) \mathrm{cm}$ dan terjadi peningkatan setelah penelitian dengan rata-rata 59,1 $(4,48) \mathrm{cm}$. Pada data pertumbuhan adalah pertumbuhan berat badan dan tinggi badan terdapat perbedaan yang signifikan sebelum dan setelah penelitian $(\rho<0,05)$. Sedangkan data perkembangan skor SDIDTK didapatkan sebelum penelitian dengan rata-rata $8,06(0,92)$ kemudian menjadi 9,13 (0,35). Pada kategori perkembangan sebanyak $50 \%$ responden dengan perkembangan meragukan, sedangkan sisanya $43,8 \%$ normal dan $6,1 \%$ penyimpangan. Setelah penelitian terdapat peningkatan menjadi $37,6 \%$ meragukan, $56,3 \%$ normal dan $6,3 \%$ penyimpangan. Pada data perkembangan skor SDIDTK dan kategori perkembangan tidak didapapatkan perbedaaan yang signifikan sebelum dan setelah penelitian $(\rho>0,05)$.

Tabel 2. Perbedaan Pertumbuhan Dan Perkembangan Bayi Sebelum Dan Sesudah Penelitian Pada Kelompok Kontrol

\begin{tabular}{llll}
\hline \multicolumn{1}{c}{ Variabel } & \multicolumn{1}{c}{ Pre } & Post & $\begin{array}{c}\boldsymbol{P} \\
\text { value }\end{array}$ \\
\hline Berat Badan (g) & & & \\
\hline Mean (SD) & $5.625,0$ & 6.118 & $<0,001^{*}$ \\
Median & $(1.216,2)$ & $(1.218)$ & \\
Rentang & 5.550 & 6.100 & \\
& $2.900-$ & $3.400-$ & \\
\hline Panjang Badan (Cm) & & \\
\hline Mean (SD) & 7.900 & 8.600 & \\
Median & $(4,56)$ & $(4,48)$ & $<0,001^{*}$ \\
Rentang & 58,5 & 60,0 & \\
Skor SDIDTK & $48-64$ & $51,0-$ & \\
Mean (SD) & \multicolumn{4}{l}{60,0} \\
\hline
\end{tabular}

\begin{tabular}{lccl}
\hline Median & 8,0 & 9,0 \\
Rentang & $6-9$ & -10 & \\
\hline \multicolumn{4}{l}{ Kategori Perkembangan } \\
Penyimpangan & 1 & 1 & \multirow{2}{*}{$0,157^{*}$} \\
\multirow{2}{*}{ Meragukan } & $(6,3 \%)$ & $(6,3 \%)$ & \\
\multirow{2}{*}{ Sesuai } & 8 & 6 & \\
& $(50,0 \%)$ & $(37,6 \%)$ & \\
& 7 & 9 & \\
\hline
\end{tabular}

Keterangan uji : *) Uji Wilcoxon

Pada tabel 2 didapatkan hasil data pertumbuhan dan perkembangan pada kelompok intervensi. Pada data pertumbuhan menurut berat badan didapatkan sebelum penelitian dengan rata-rata 5.286 (1445) gram dan terjadi peningkatan setelah penelitian menjadi dengan rata-rata 5.946 (1.136) gram. Pada data panjang badan didapatkan sebelum penelitian dengan rata-rata $54,3(4,13) \mathrm{cm}$ dan terjadi peningkatan setelah penelitian dengan rata-rata 56,2(4,2) $\mathrm{cm}$. Pada data pertumbuhan adalah pertumbuhan berat badan dan tinggi badan terdapat perbedaan yang signifikan sebelum dan setelah penelitian $(\rho<0,05)$. Sedangkan data perkembangan skor SDIDTK didapatkan sebelum penelitian dengan rata-rata $7,87(1,12)$ kemudian menjadi $9,13(1,14)$. Pada kategori perkembangan sebanyak $60 \%$ responden dengan perkembangan sesuai, sedangkan sisanya $26,7 \%$ meragukan dan 13,3\% penyimpangan. Setelah penelitian terdapat peningkatan dan seluruh responden memiliki perkembangan yang normal 100\%. Pada data perkembangan skor SDIDTK dan kategori perkembangan didapatkan perbedaan yang signifikan sebelum dan setelah penelitian $(\rho<0,05)$.

Tabel 3. Perbedaan Pertumbuhan Dan Perkembangan Bayi Sebelum Dan Sesudah Penelitian Pada Kelompok Intervensi

\begin{tabular}{cccc}
\hline Variabel & Pre & Post & $P$ \\
\hline
\end{tabular}




\begin{tabular}{|c|c|c|c|}
\hline & & & value \\
\hline \multicolumn{4}{|l|}{ Berat Badan (g) } \\
\hline Mean (SD) & $\begin{array}{l}5.286 \\
(1445)\end{array}$ & $\begin{array}{l}5.946 \\
(1.136)\end{array}$ & $<0,001 *$ \\
\hline Median & 5.800 & 6.400 & \\
\hline Rentang & $\begin{array}{l}2.300- \\
7.000\end{array}$ & $\begin{array}{l}3.900- \\
7.400\end{array}$ & \\
\hline \multicolumn{4}{|c|}{ Panjang Badan (cm) } \\
\hline Mean (SD) & $\begin{array}{c}54,3 \\
(4,13)\end{array}$ & $\begin{array}{c}56, \\
2(4,2)\end{array}$ & $<0,001 *$ \\
\hline Median & 55,0 & 57,0 & \\
\hline Rentang & $49-60$ & $51-63$ & \\
\hline \multicolumn{4}{|l|}{ Skor SDIDTK } \\
\hline Mean (SD) & $\begin{array}{c}7,87 \\
(1,12)\end{array}$ & $\begin{array}{c}9,13 \\
(1,14)\end{array}$ & $0,003 *$ \\
\hline Median & 8,0 & 9,0 & \\
\hline Rentang & $6-9$ & $9-10$ & \\
\hline \multicolumn{4}{|c|}{ Kategori Perkembangan } \\
\hline Penyimpangan & $\begin{array}{c}2 \\
(13,3 \%)\end{array}$ & $\begin{array}{c}0 \\
(0 \%)\end{array}$ & $0,023 *$ \\
\hline Meragukan & $\begin{array}{c}4 \\
(26,7 \%)\end{array}$ & $\begin{array}{c}0 \\
(0 \%)\end{array}$ & \\
\hline Sesuai & $\begin{array}{c}9 \\
(60,0 \%)\end{array}$ & $\begin{array}{c}15 \\
(100 \%)\end{array}$ & \\
\hline
\end{tabular}

Keterangan uji : *) Uji wilcoxon

Pada tabel 3 hasil pada data selisih pertumbuhan berat badan kelompok kontrol sebesar 493,7 (308,6) gram sedangkan pada kelompok intervensi lebih banyak yaitu 660,0 $(445,29)$ gram, namun demikian hasil uji statistik tidak menunjukkan perbedaan bermakna peningkatan berat badan pada kedua kelompok $(\rho>0,05)$. Hasil pada data selisih pertumbuhan panjang badan kelompok kontrol sebesar 1,62 $(0,95) \mathrm{cm}$ sedangkan pada kelompok intervensi lebih banyak yaitu $1,86(0,51) \mathrm{cm}$, namun demikian hasil uji statistik tidak menunjukkan perbedaan bermakna peningkatan panjang badan pada kedua kelompok $\quad(\rho>0,05)$. Pada data perkembangan skor SDIDTK didapatkan hasil pada data selisih perkembangan kelompok kontrol sebesar 0,18 $(0,4)$ sedangkan pada kelompok intervensi lebih banyak yaitu 1,26 (1,03), sehingga hasil uji statistik menunjukkan perbedaan bermakna peningkatan panjang badan pada kedua kelompok $(\rho<0,05)$. Berdasarkan hal tersebut didapatkan tidak ada perbedaan bermakna booklet SDIDTK pada data pertumbuhan, namun terdapat perbedaan bermakna pada data perkembangan.

Tabel 4. Pengaruh Penerapan Booklet Stimulasi Intervensi Pertumbuhan Dan Perkembangan

\begin{tabular}{|c|c|c|c|}
\hline Variabel & Kontrol & Perlakuan & Pvalue \\
\hline \multicolumn{4}{|c|}{$\Delta$ Berat Badan $(g)$} \\
\hline Mean (SD) & $\begin{array}{c}493,7 \\
(308,6)\end{array}$ & $\begin{array}{c}660,0 \\
(445,29)\end{array}$ & \multirow[t]{3}{*}{$0,234^{*}$} \\
\hline Median & 450,0 & 500,0 & \\
\hline Rentang & $100-1300$ & $100-1600$ & \\
\hline \multicolumn{4}{|c|}{$\underline{\Delta}$ Panjang Badan (cm) } \\
\hline Mean (SD) & $\begin{array}{c}1,62 \\
(0,95)\end{array}$ & $\begin{array}{c}1,86 \\
(0,51)\end{array}$ & \multirow[t]{3}{*}{$0,163 * *$} \\
\hline Median & 1,0 & 2,0 & \\
\hline Rentang & $1-4$ & $1-3$ & \\
\hline \multicolumn{4}{|c|}{$\Delta$ Skor SDIDTK } \\
\hline Mean (SD) & $\begin{array}{l}0,18 \\
(0,4)\end{array}$ & $\begin{array}{c}1,26 \\
(1,03)\end{array}$ & \multirow[t]{3}{*}{$0,002 *$} \\
\hline Median & 0,0 & 1,0 & \\
\hline Rentang & $0-1$ & $0-3$ & \\
\hline
\end{tabular}

Keterangan uji : *) Mann Whitney, **) T Independent

\section{PEMBAHASAN}

Semakin pendek masa kehamilan, semakin besar risikonya kematian dan morbiditas untuk bayi. Bayi prematur memiliki risiko kematian di tahun pertama kehidupan terutama karena prematuritas. Pentingnya pertumbuhan bayi prematur adalah menerima perhatian, stimulasi untuk perkembangan jangka panjang. Sayangnya, pertumbuhan sering merupakan masalah sekunder saat perawatan pasca lahir yang diutamakan adalah pada stabilisasi dan pengelolaan penyakit akut. Tenaga kesehatan harus memberikan stimulasi ritmik yang lembut 
bentuk sentuhan lembut, pijatan, memeluk, membelai dan melenturkan Stimulus pendengaran yang menenangkan dapat diberikan pada bayi prematur dalam bentuk suara keluarga atau musik (Fayed NM, 2016).

Pemerintah memberikan solusi untuk mendeteksi penyimpangan pertumbuhan dan perkembangan anak melalui program Stimulasi Deteksi dan Intervensi Tumbuh Kembang (SDIDTK) yang telah ada sejak tahun 1988. Pemantauan SDIDTK diantaranya dengan melakukan pemantauan motorik kasar dan motorik halus pada bayi dan balita dengan menggunakan Kueisioner Pra Skrining Perkembangan ( KPSP ). Sehingga penyimpangan pertumbuhan dan perkembangan dapat terdeteksi dini (Depkes,2015)

Stimulasi secara dini merupakan salah satu faktor yang mempengaruhi tumbuh kembang bayi. Stimulasi dapat merangsang hubungan antar sel otak (sinaps), miliaran sel otak dibentuk sejak kehamilan berusia 6 bulan yang pada saat itu belum ada hubungan antar sel otak. Saat ada rangsangan, maka akan terbentuk hubungan. Sering memberikan rangsangan dapat menguatkan hubungan sinaps. Variasi rangsangan akan membentuk hubungan yang semakin luas dan kompleks. Pada keadaan yang seperti ini, otak kanan maupun kiri dapat terslimulasi sehingga terbentuk multiple intelegent dan juga kecerdasan yang lebih luas dan tinggi (Destiana, 2017).

Stimulasi dimaksudkan untuk melatih kemampuan bayi agar bayi dapat menguasai ketrampilan tertentu pada usia yang seharusnya. Cukup banyak kejadian keterlambatan perkembangan terjadi hanya karena kurangnya stimulasi. Banyak kemampuan sebenarnya telah dapat mulai dipelajari sejak dini (Destiana, 2017).

Pada tabel 1 dan tabel 2 data pertumbuhan kelompok kontrol menunjukkan pertambahan pertumbuhan yang signifikan. Hal ini dikarenakan bayi 0-6 bulan mengalami proses pertumbuhan yang cepat dan penambahan berat badan yang signifikan. Baik pada kelompok kontrol maupun kelompok perlakuan keduanya terdapat perbedaan yang signifikan penambahan berat badan sebelum dan setelah penelitian.

Hal ini sesuai dengan kajian Supariasa (2016) menyatakan bahwa pertumbuhan berkaitan dengan perubahan dalam besar, jumlah, ukuran, dan fungsi tingkat sel, organ maupun individu, yang diukur dengan ukuran berat (gram, pound, kilogram), ukuran panjang ( $\mathrm{cm}$, meter), umur tulang dan keseimbangan metabolik (retensi kalsium dan nitrogen tubuh). Pertumbuhan fisik merupakan hal yang kuantitatif, yang dapat diukur. Indikator ukuran pertumbuhan meliputi perubahan tinggi dan berat badan, gigi, struktur skelet, dan karakteristik seksual.

Pada penelitian ini parameter pertumbuhan menggunakan berat badan dan tinggi badan. Sebagai salah satu cara ukur dari metode penilaian pertumbuhan, berat badan berfungsi untuk menggambarkan jumlah protein, lemak, air, dan mineral pada tulang Panjang Badan adalah parameter yang cukup penting bagi keadaan masa lalu dan masa sekarang karena dengan menghubungkannya dengan berat badan (quac stick), faktor umur dapat dikesampingkan (Supariasa, 2016).

Faktor umur sangat penting dalam penentuan pertumbuhan. Hasil pengukuran tinggi badan dan berat badan yang akurat, menjadi tidak berarti jika 
disertai dengan penentuan umur yang tepat ( Supariasa, 2016 ). Oleh sebab itu penambahan berat badan yang signifikan dikarenakan memang proses pertumbuhan yang cepat pada masa 0-6 bulan. Selain itu kelompok kontrol juga mendapatkan edukasi dari buku KIA tentang pertumbuhan bayi.

Faktor - faktor yang Mempengaruhi Pertumbuhan Supariasa (2016) Mengatakan pertumbuhan dipengaruhi oleh dua faktor utama yaitu faktor internal seperti biologis, termasuk genetik, dan faktor eksternal seperti status gizi. Faktor - faktor eksternal yang mempengaruhi pertumbuhan antara lain keluarga, stimulasi, kelompok teman sebaya, pengalaman hidup, kesehatan lingkungan, kesehatan prenatal, nutrisi, istirahat, tidur dan olah raga, status kesehatan, serta lingkungan tempat tinggal. Pada penelitian ini bayi prematur diberikan intervensi stimulasi. Pada kelompok kontrol melalui buku KIA sedangkan pada kelompok intervensi melalui booklet SDIDTK. Hasil yang didapatkan keduanya menunjukkan adanya peningkatan berat badan dan panjang badan yang signifikan.

Pertumbuhan berkorelasi dengan perkembangan Penelitian yang dilakukan oleh Moonik (2015) membuktikan bahwa berat lahir yang rendah memiliki hubungan bermakna terhadap keterlambatan perkembangan anak dimana $\mathrm{p}=0,042$ dengan $\mathrm{OR}=2,4$. Selain itu dari segi lingkungan memiliki peran penting dalam perkembangan anak. Kepadatan hunian memiliki hubungan bermakna terhadap keterlambatan dengan $\mathrm{p}$ value 0,038 .

Pada tabel 2 dan 3 menunjukkan data perkembangan sebelum dan setelah penelitian. Pada kelompok kontrol tidak didapatkan peningkatan yang signifikan pekembangan bayi, hal ini berbeda dengan kelompok intervensi yang menunjukkan penggunaan booklet SDIDTK dapat meningkatkan perkembangan secara signifikan sebelum dan setelah penelitian.

Perkembangan adalah bertambahnya kemampuan (Skill) dalam struktur dan fungsi tubuh yang lebih kompleks dalam pola yang teratur dan dapat diramalkan, sebagai hasil dari proses pematangan.

Tahap perkembangan adalah tahaptahap yang harus dilalui bayi dalam proses perkembangan motorik sesuai dengan umur dan harus melalui prinsip perkembangan motorik yang benar. Sedangkan perkembangan motorik yang dimaksud dengan perkembangan motorik adalah proses tumbuh kembang kemampuan gerak seorang anak yang dikoordinasi oleh saraf, pusat saraf dan otot. Secara umum perkembangan motoric dibagi enjadi dua yaitu motor kasar dan motor halus (Soetjiningsih, 2015)

Deteksi dini melalui kegiatan SDIDTK sangat diperlukan untuk menemukan secara dini penyimpangan pertumbuhan, penyimpangan perkembangan dan penyimpangan mental emosional pada anak sehingga dapat dilakukan intervensi dan stimulasi sedini mungkin untuk mencegah terjadinya penyimpangan pertumbuhan, perkembangan dan mental emosional yang menetap. Kegiatan SDIDTK tidak hanya dilakukan pada anak yang dicurigai mempunyai masalah saja tetapi harus dilakukan pada semua balita dan anak pra sekolah secara rutin setahun 2 kali (Rini S, 2016

Pada tabel 4 menunjukkan selisih data pertumbuhan baik berat badan 
maupun selisih panjang badan pada kelompok intervensi lebih banyak bila dibandingkan dengan kelompok kontrol. Namun hasil uji statistik menunjukkan perbedaan yang tidak bermakna pada selisih data pertumbuhan.

Meskipun penelitian ini tidak menunjukkan perbedaan yang bermakna pada selisih pertumbuhan bayi, namun demikian hasil tetap menunjukkan selisih pertumbuhan pada kelompok intervensi lebih baik bila dibandingkan dengan kelompok kontrol. Pada selisih pertumbuhan berat badan kelompok intervensi lebih berat yaitu 660,0 $(445,29)$ gram, sedangkan pada kelompok kontrol hanya sebanyak 493,7 $(308,6)$ gram. Pada selisih panjang badan menunjukkan kelompok intervensi lebih panjang yaitu $1,86(0,51) \mathrm{cm}$, sedangkan pada kelompok kontrol hanya sebanyak 1,62 $(0,95) \mathrm{cm}$. Hal ini mampu menunjukkan bahwa booklet SDIDTK dapat meningkatkan pertumbuhan lebih cepat bila dibandingkan kelompok kontrol.

Suatu penelitian yang dilakukan Fayed tahun 2016 menjelaskan bahwa intervensi stimulasi tumbuh kembang pada bayi prematur dapat memberikan dampak positif terhadap penambahan berat badan dan perkembangan bayi. Penelitian ini merekomendasikan diperlukan standarisasi intervensi tumbuh kembang terutama pada bayi prematur yang berat badannya sangat rendah.

Pada tabel 4 juga menunjukkan data perkembangan pada kelompok intervensi dan kelompok kontrol. Skor SDIDTK pada kelompok intervensi lebih tinggi bila dibandingkan dengan kelompok kontrol. Hasil uji statistik juga menjelaskan bahwa terdapat perbedaan yang signifikan selisih perkembangan pada bayi. Hal ini menunjukkan adanya pengaruh yang signifikan penerapan booklet SDIDTK terhadap perkembangan bayi.

Perkembangan sangat penting untuk dipantau, idealnya setiap anak harus mendapatkan pemantauan pertumbuhan dan perkembangan dari tenaga medis terlatih secara berkala, untuk mencegah adanya gangguan tumbuh kembang lanjut yang sulit ditangani. Semakin terlambat gangguan dideteksi, semakin sulit penanganannya (Destiana, 2017)

Penelitian yang dilakukan oleh Dewi, Feti menunjukkan bahwa SDIDTK terbukti efektif terhadap peningkatan angka penemuan dini gangguan pertumbuhan dan perkembangan anak usia balita dengan $\mathrm{p}$ value 0,004. Hal yang sama pada penelitian yang dilakukan Fayed tahun 2016 menjelaskan bahwa intervensi stimulasi tumbuh kembang pada bayi prematur dapat memberikan dampak positif terhadap penambahan berat badan dan perkembangan bayi.

Berdasarkan penelitian Saldi Fitra tahun 2013, stimulasi berpengaruh terhadap peningkatan perkembangan bicara anak 1-3 tahun di daerah GAKY dan Non GAKY. Menurut Soedjatmiko tahun 2006, stimulasi dini penting dilakukan untuk merangsang perkembangan bayi dan balita terutama pada bayi risiko tinggi (Destiana, 2017).

Pemberian stimulasi tersebut harus diimbangi dengan pemeriksaan deteksi dini tumbuh kembang oleh petugas kesehatan atau orang tua, dinilai dengan menggunakan KPSP sehingga dapat diketahui perkembangan bayi. KPSP mudah dimengerti dan bisa dijumpai pada kegiatan posyandu, aplikasi PRIMA, internet dan petugas kesehatan. Hal ini dapat membantu menemukan penyimpangan tumbuh kembang anak secara dini, sehingga intervensi atau 
rencana tindakan akan lebih mudah dilakukan (Destiana, 2017).

Menurut penelitian Widaningsih (2012) yang dilakukan pada anak usia 424 bulan menjelaskan bahwa, Pengaruh Stimulasi Deteksi Dini Tumbuh Kembang (DDTK) dapat meningkatkan perkembangan anak.

Stimulasi dan Deteksi dini dengan menggunakan booklet SDIDTK sangat diperlukan untuk menemukan secara dini penyimpangan pertumbuhan, penyimpangan perkembangan dan penyimpangan mental emosional pada anak sehingga dapat dilakukan stimulasi sedini mungkin untuk mencegah terjadinya penyimpangan pertumbuhan, penyimpangan perkembangan dan penyimpangan mental emosional yang menetap. Kegiatan DDTK tidak hanya dilakukan pada anak yang dicurigai mempunyai masalah saja tetapi harus dilakukan pada semua anak

\section{KESIMPULAN DAN SARAN}

Kesimpulan pada penelitian ini adalah tidak Terdapat Pengaruh penerapan booklet stimulasi intervensi pertumbuhan pada bayi $(\rho>0,05)$, namun terdapat pengaruh perkembangan pada bayi riwayat prematur $(\rho<0,05)$ usia $0-6$ bulan di Kabupaten Karanganyar. Disarankan untuk dapat melakukan penelitian tindak lanjut tentang booklet SDIDTK pada sampel yang lebih luas. Selain itu untuk dapat mengembangkan booklet SDIDTK ini agar dapat memberikan pengaruh pertumbuhan yang signifikan pada anak.

\section{DAFTAR RUJUKAN}

Destiana R, Yani ER, Yanuarini TA. 2017. Kemampuan Ibu Melakukan Stimulasi Untuk Perkembangan
Bayi Usia 3-6 Bulan Di Wilayah Kerja Puskesmas Puhjarak Kabupaten Kediri. Journal Ilmu Kesehatan, 6(1), 10

Fayed NM. 2016. Effect of Physical Stimulation on Prematur Very Low Birth Weight Infants. American Journal of Nursing Research, 4(1).

Kemenkes RI 2012. Survey Demografi Kesehatan Indonesia. Jakarta

Kemenkes RI, 2015. Buku Ajar Kesehatan Ibu dan Anak. Jakarta:

Kemenkes. 2016. Pedoman Pelaksanaan. Stimulasi, Deteksi dan Intervensi Dini Tumbuh Kembang Anak Di tingkat Pelayanan Dasar. Kemenkes RI.

Mubarak WI, Chayatin, Rozikink, \& Supriadi. 2012. Promosi Kesehatan. Yogyakarta: Graha Ilmu.

Murray, e. a. 2006. Infant Motor Development is Associated with Adult Cogitive Categorisation in a Longitudinal Birth Cohort Study. Journal of Child Psychology and Psychiatry.

Rafaela S. Moreiraa, L. C. M., Claudia R.L. Alves. 2014. Effect Of Preterm Birth On Motor Development, Behavior, Andschool Performance Of School-Age Children: a Systematicreview. J Pediatr, 90(2), 16.

Soetjiningsih, \& Gde Ranuh, I. N. 2015. Tumbuh Kembang Anak. Jakarta: EGC.

Supariasa, I. N., Bakri, B., \& Fajar, I. 2016. Penilaian Status Gizi. Jakarta: EGC.

Widaningsih I, Darajat AM, Dirgahay I. 2012. Pengaruh Stimulasi Deteksi Dini Tumbuh Kembang (DDDTK) Terhadap Perkembangan Anak Usia 4-24 Bulan Di Wilayah Kerja 
84 Jurnal Kebidanan dan Kesehatan Tradisional, Volume 4, No 2, September 2019, hlm 57-119

Puskesmas Cinunuk Kabupaten BandungI. Journal Bhakti Kencana Medika, 2 (4),5.

Wong, D. L. 2009. Buku Ajar Keperawatan Pediatrik. Jakarta: EGC 